\title{
Boiling Behavior of a Droplet Impinging on a Heated Surface
}

\author{
機正 ○稲田 茂昭（群馬大） 松元 純一（群馬大 学生）
}

Shigeaki INADA, Dept. of Mech. System Eng., Gunma University, Jun ichi MATSUMOTO 1-5-1, Tenjincho, Kiryu 376-8515

Key Words: Boiling Behavior, Impinging Droplet, Heated Quartz Surface, Heated ITO Surface, Evaporation Lifetime, High-Speed Photograph

\section{1. 緒言}

加熱固体面に衝突する液滴の沸腾蒸発現象は, 最初に Tamura and Tanasawa (1)によって研究され, その挙動之最 大蒸発率点及びライデンフロスト点を含む蒸発寿命曲線が 明らかにされた. その後, Baumeister and Simon (2)，西 尾・平田 (3)によってライテンフロスト点と液滴の挙動に 及ぼす加熱面材質の影響が報告され, Temple-Pediani (4) は熱伝導率の良好な加熱面では蒸発特性が良いため, 最大 蒸発率点が明瞭に現れないこと, 更に Takano and Kobayashi (5) は逆に熱伝導率の低いセラミックス加熱面では蒸発 特性の良好な範囲が高温域まで広がることを報告している。 また Makino and Michiyoshi ${ }^{(6)}$ は熱物性の異なる種々の金 属加熱面で液滴との固液接触時間を実測し, 加熱面温度と の相関式を提案している.このように加熱面材質に関して の研究は最大蒸発率点かライデンフロスト点に集中してお り，遷移沸騰域における研究は少ない.

本研究の目的は, 加熱面衝突時において遷移沸騰域で認 められる多数の微小な液滴が大気雾囲気中へ激しく飛散す る微細化現象を明らかにすることにある. 特に初期固液接 触面内 (濡れ面内) で発生する微小気泡の発生挙動をとら え，微細化の機構と関連づけようとするものである.

前報 (7) において使用した石英加熱面では核沸騰的な挙 動が高温域まで続き, 激しい微細滴の飛散現象が顕著に認 められなかったため, 本報ではガラス面に薄く導電性皮膜 を施した ITO (Indium Tin Oxide : 酸化インジウム スズ) 皮膜加熱面を使用し, 石英面と比較した.

\section{2. 実験装置及び方法}

実験装置の概略を図 1 に示す，加熱面には直径 $50 \mathrm{~mm}$ ，長 さ $40 \mathrm{~mm}$ ，その両端面がレンズ状に磨かれた石英円柱が使用 された.この石英の他に, 板厚 $1.8 \mathrm{~mm}$ のガラス基板表面に $0.15 \mu \mathrm{m}$ 厚さで薄く導電性皮膜を施した IT0 皮膜加熱面を 使用した。これは石英円柱面上に置くことによって加熱さ れた，石英円柱はカートリッジヒータが円周方向に均等に 埋め込まれた加熱円柱ブロックの中心にその軸に沿って挿 入され，周囲から均一に熱伝導によって加熱される. 石英 円柱及び ITO 基板の上面は水平に保持され，この面の中心 に水滴が垂直に滴下される，水滴には充分に脱気された蒸 留水を使用し, 水温 $16^{\circ} \mathrm{C}$, 水滴直径 $3.5 \mathrm{~mm}$, 落下高さ $65 \mathrm{~mm}$ に保持した. 本実験での衝突ウェーバ数は We $=61$, 液滴の自 由振動周期は約 $\tau_{\mathrm{r}}=19 \mathrm{~ms}$ である.

水滴衝突面である石英及び ITO 基板面の温度はその面に 熱電対を 2 䉪所セラミックス系接着郕で貼り付けて測定し た. 液滴は常時一定の周期で滴下させておき, これをシャ ッターで受け止め, 実験時にはシャッターを移動させるこ とによって一滴のみ落下させる.
現象撮影は石英円柱の裹面から高速度ピテオカメラで行 った.

\section{3. 結果及び考察}

\section{1 液滴寿命曲線}

図 2 は初期衝突面温度 $T_{w o}$ に対する液滴の蒸発寿命時間を示 す. 寿命時間の計測はストップウォッチと高速度カメラの撮影 結果との両方で行った. 衝突面の材質が金属と違って, セラミ ックス面のような熱物性值 $\left(\mathrm{C}_{\mathrm{p}} \rho \lambda\right)^{1 / 2}$ の小さい材質面では寿命 時間の短い期間が高温度までその領域が広がることが Takano and Kobayashi ${ }^{(5)}$ によって報告されている. C ぞれ衝突面の比熱, 密度, 熱伝導率を示す. 本報の石英の場合, 上記熱物性值はセラミックスの約 1.6 倍に相当するが, この場 合も寿命時間の短い期間が高温度までその領域が広がっている. 図 2 中に示した一点鎖線は Makino and Michiyoshi ${ }^{(6)}$ によって 整理された金属の熱物性值, 水滴直径及び衝突面温度を考慮し た核沸騰域の接触時間 $\tau_{\mathrm{t}}$ で，これを寿命時間 $\tau_{\mathrm{c}}$ として本報で の水滴直径及び石英面に適用したものである.これによると本 報の加熱面温度範囲では核沸騰域での現象範囲に属するが, 寿命時間は金属面よりも長く, 特に石英面では $300^{\circ} \mathrm{C}$ 以上で は更に長くなる傾向にある。これに対して ITO 面では片対 数グラフ上において加熱面温度の上昇と共に淔線状に寿命 時間は減少している.

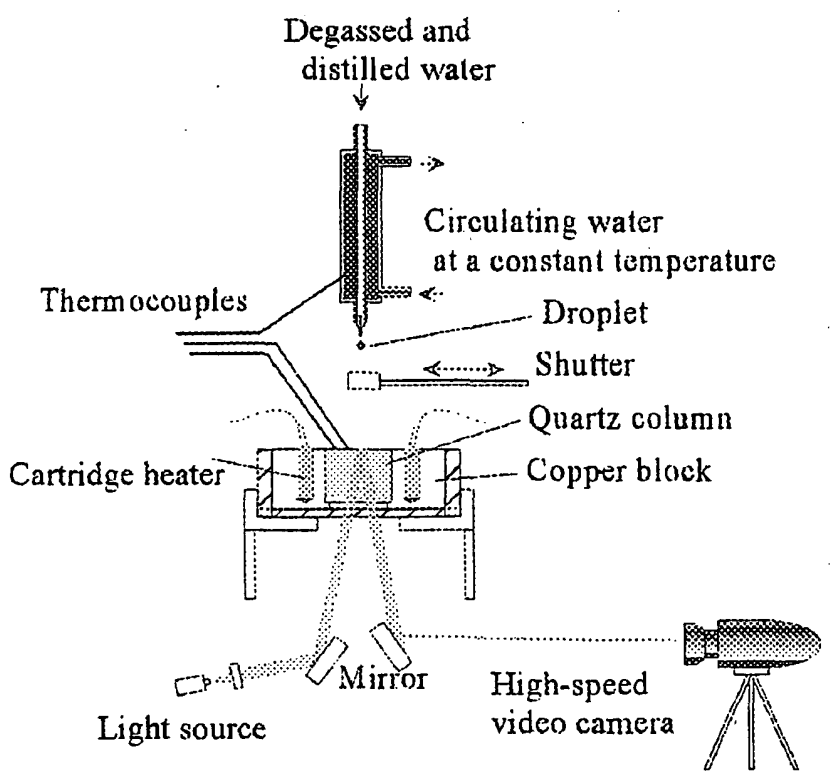

Fig. 1 Experimental apparatus 


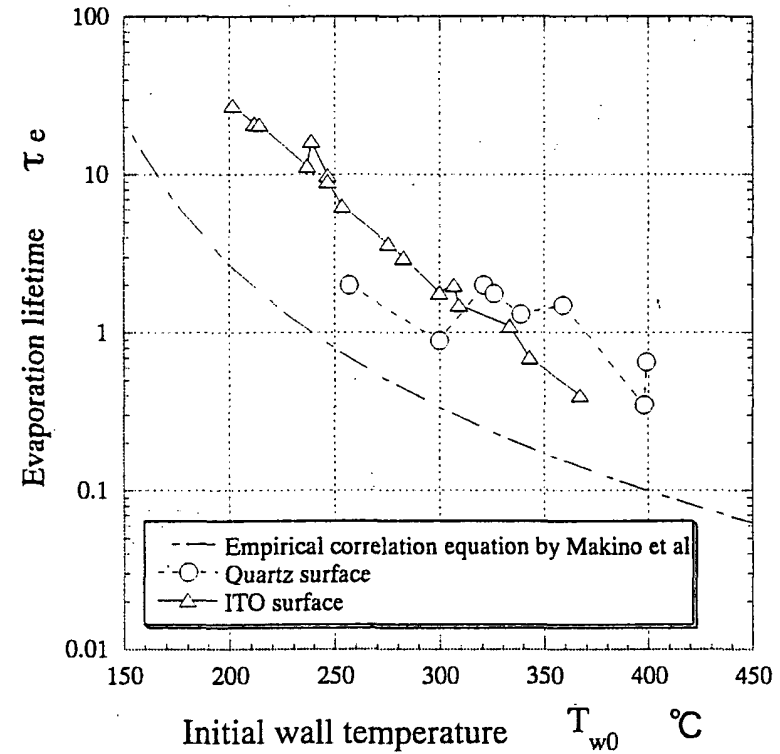

Fig. 2. Evaporation lifetime curve

\subsection{IT0 面上での液滴の沸騰挙動}

図 3 はIT0 面の温度が $202^{\circ} \mathrm{C}$ 場合におけるその面上での 液滴の沸騰挙動を示す. 各写真の下の数值は衝突後の経過 時間である，液滴は衝突時点から円形に広がり，12ms では 最大径に達している.この間液滴は広がりながらその周辺 に液膜が盛り上がったクレ一்タ状を示す。そして液膜内に 微小な蒸気泡の発生とみなされる白い斑点が多数観察され る.これらの白い点は液膜の中央部から放射状に周辺部へ 速い速度で移動しているのがわかる（8ms）。その結果, 液 膜の周辺部では白い斑点の数が増え, 液膜の中央部には斑 点の数が計測できる程度に鮮明に写し出されている

(12ms)．引続き, 周辺部から中央のクレータ部に问かっ て液の押し寄せが開始されると, 白い斑点の発生は顕著に 認められず，斑点同士の合体によって白い斑点はその大き さを増す（16ms-28ms）。32ms ではクレー夕状は消滅し，液 膜は滴状に復元する. 最大広がり径に達した後, 滴状に復 元するまでの間はその広がり径（固液接触による濡れ面 積）は，ほぼ一定に保たれている。滴状に復元した後は液 滴内に比較的大きなドーム状の蒸気泡が発生して蒸発が終 了する.

この温度と同程度の石英面での液滴の蒸発挙動は液膜の 広がり径の変化や白い斑点の発生の有無に関して IT0 面と 大きく異なっている.

ITO 面の温度が $370^{\circ} \mathrm{C}$ の場合; 液滴の広がり径の時間変化 は図 3 に示した $202^{\circ} \mathrm{C}$ 場合と同様であるが，最大広がり径 に達した時点で微小気泡の発生（図 3 亡同様に白い微小な 斑点の発生で確認できた）と同時に多数の微小な液滴が大 気中へ激しく飛散する現象が確認された。また微小気泡同 士の合体も生じ，その合体泡の射出に伴って比較的粗粒な 液粒子となって飛散する現象も確認され，早い時期に蒸発 が終了することが判明した．この $370^{\circ} \mathrm{C} の 1 \mathrm{~T} 0$ 面の温度と同 程度の石英面で観察された液滴の蒸発挙動においては, 上 記の激しい微小な液滴の飛散は認められなかった。
(1) Tamura, Z. and Tanazawa, Y., Proc. 7th Symp. on Combust., (1958), 509.

(2) Baumeister, K. J. and Simon, F. F., J. of Heat Transfer, Vol. 95, (1973), 166.

（3）西尾, 平田, 機論, 44-380（昭 53-4)，1335.

(4) Temple-Pediani,R. W., Proc. IMECHE, Vol. 184, (1969), 677.

(5) Takano, T. and Kobayashi, K., Heat Transfer Japanese Research, Vol. 20, (1991), 1.

(6) Makino, K. and Michiyoshi, I., Int. J. Heat Mass Transfer, 27-5, (1984), 781.

( 7 ) Inada, S., Yang, W.-J. and Kawahara, Y., Proc. of the 4 th JSME-KSME Thermal Engineering Conf., Vol. 1, (2000), 331.

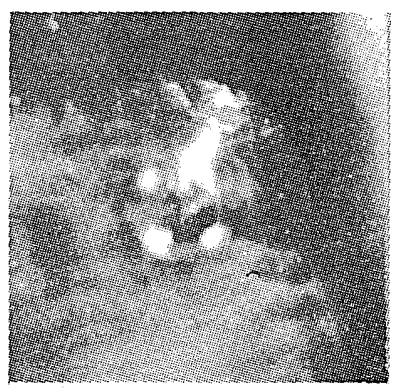

$4 \mathrm{~ms}$

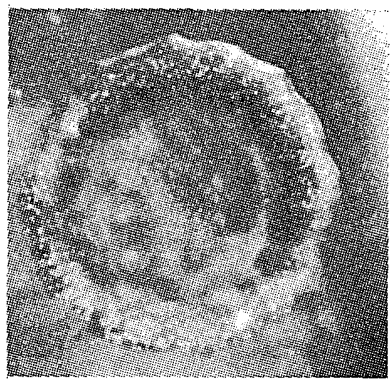

$12 \mathrm{~ms}$

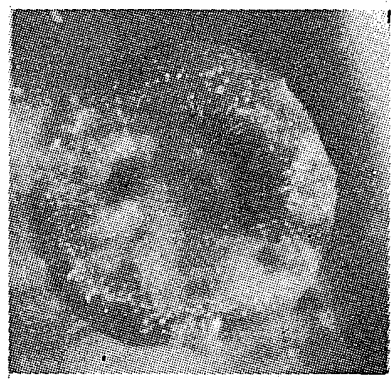

$20 \mathrm{~ms}$

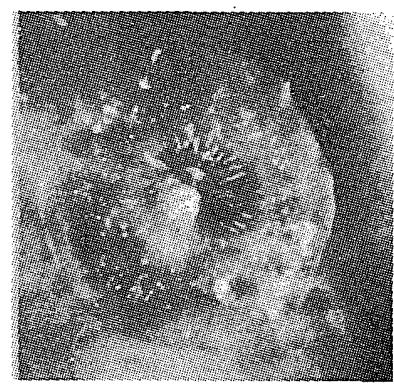

$28 \mathrm{~ms}$

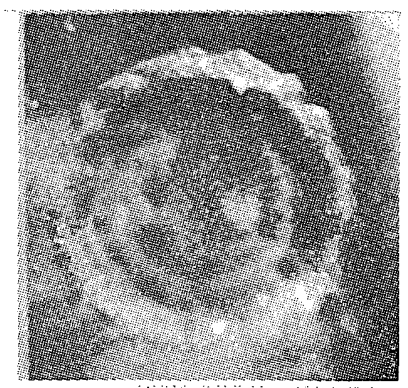

$8 \mathrm{~ms}$

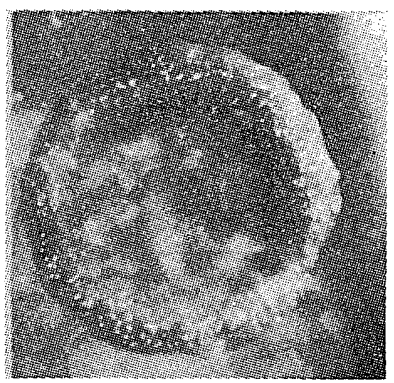

$16 \mathrm{~ms}$

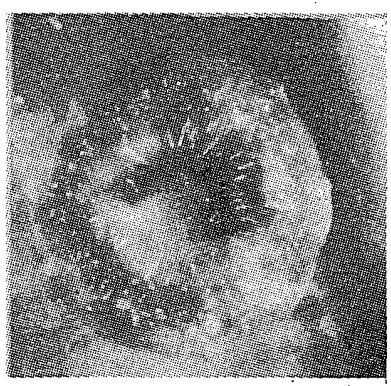

$24 \mathrm{~ms}$

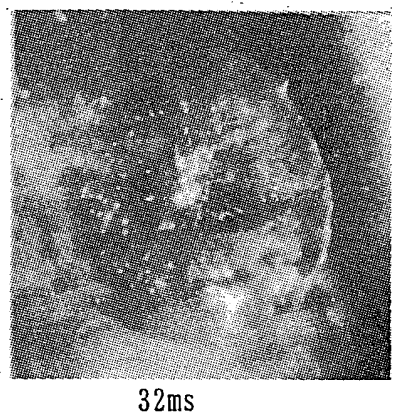

Fig. 3 Boiling behavior of a droplet impinging on the ITO surface $\left(\mathrm{T}_{\mathrm{w} 0}=202^{\circ} \mathrm{C}\right)$ 